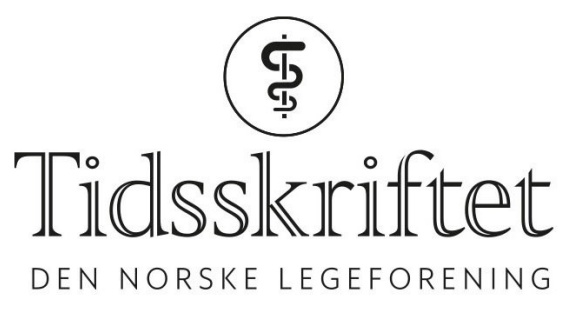

\title{
Hva er meningsfulle effektstørrelser ved depresjonsbehandling?
}

KOMMENTAR

\section{ULRIK FREDRIK MALT}

E-post: u.f.malt@medisin.uio.no

Ulrik Fredrik Malt er overlege og professor emeritus

Oppgitte interessekonflikter: Malt har gjennomført en undersøkelse av effektene av SSRI ved depresjoner i norsk allmennpraksis, og har skrevet artikler hvor han konkluderer med at SSRI har klinisk meningsfulle effekter. Han har også vært viseleder for Verdens psykiaterforenings utvalg for farmakoterapi som også har konkludert med at SSRI har klinisk meningsfulle effekter. Han har dessuten holdt foredrag og kurs arrangert både av ikke-kommersielle og kommersielle arrangører om psykofarmakologi, heri inkludert bruk av antidepressive legemidler.

Malt mener at «kriteriene for å vurdere effekten av et medikament kan varieres etter behov» skriver Gjerden. Det er en underlig anførsel. Ved behandling av ikke-bipolare depresjoner med medikasjon (og psykoterapi) er effektstørrelsene o,25-0,5, vurdert ut fra reduksjon av skår på en graderingsskala når effekten av støttebehandling kombinert med placebo eller ikke-spesifikk samtalebehandling er trukket fra. Sammenlignende studier viser ingen effektforskjeller mellom medikasjon og psykoterapi (1). Hovedpoenget i debatten er om slike effektstørrelser er klinisk meningsfulle. Jeg mener det.

At man både ved psykoterapi og medikasjon kan finne høyere effektstørrelser (2) og mer differensierte behandlingsforskjeller (3) ved blant annet å bruke mer homogene skalaer for å måle effekt, er et viktig om enn sekundært poeng i debatten. Påpekning av dette innebærer ikke at effektvurderinger av legemidler (eller psykoterapi) varieres etter behov, men det er av betydning for videre forskning.

\section{LITTERATUR:}

1. Amick HR, Gartlehner G, Gaynes BN et al. Comparative benefits and harms of second generation antidepressants and cognitive behavioral therapies in initial treatment of major depressive disorder: systematic review and meta-analysis. BMJ 2015; 351: h6o19. [PubMed][CrossRef]

2. Bech P, Tanghøj P, Andersen HF et al. Citalopram dose-response revisited using an alternative psychometric approach to evaluate clinical effects of four fixed citalopram doses compared to placebo 
in patients with major depression. Psychopharmacology (Berl) 2002; 163: 20 - 5. [PubMed][CrossRef]

3. Chekroud AM, Gueorguieva R, Krumholz HM et al. Reevaluating the efficacy and predictability of antidepressant treatments: A symptom clustering approach. JAMA Psychiatry 2017; 74:370 - 8.

[PubMed][CrossRef]

Publisert: 21. august 2017. Tidsskr Nor Legeforen. DOI: 10.4045/tidsskr.17.0670

(C) Tidsskrift for Den norske legeforening 2020. Lastet ned fra tidsskriftet.no 